Pemberitahuan retraksi artikel:

\title{
Pengaruh Pemberian Terapi Tambahan Curcuma longa dan Boswellia serrata pada NSAID Terhadap Aktivitas Fungsional pada Pasien Osteoarthritis
}

\section{The Effect of Additional Therapy of Curcuma longa and Boswellia serrata on NSAIDs on Functional Activity in Osteoarthritis Patients}

Rizaldy Taslim Pinzon ${ }^{1 *}$, Jessica Herwanto ${ }^{2}$

${ }^{1}$ Departemen Neurologi, Fakultas Kedokteran, Universitas Kristen Duta Wacana, Yogyakarta, Indonesia

${ }^{2}$ Mahasiswa Program Studi Farmasi Fakultas Farmasi Universitas Sanata Dharma, Yogyakarta, Indonesia

Artikel ini telah diretraksi dari Pharmacon: Jurnal Farmasi Indonesia 17(2), 121-132, Desember 2020, atas permintaan dari penulis dan persetujuan dari dewan editor.

Editor Pharmacon: Jurnal Farmasi Indonesia mohon maaf atas terjadinya kesalahan yang menyebabkan terpublikasinya artikel tersebut. 